\title{
Supplementary material for: Jena Soil Model: a micro- bial soil organic carbon model integrated with nitrogen and phosphorus processes
}

Lin $\mathrm{Yu}^{1}$, Bernhard Ahrens ${ }^{1}$, Thomas Wutzler ${ }^{1}$, Marion Schrumpf ${ }^{1,2}$, Sönke Zaehle ${ }^{1,2}$

${ }^{1}$ Max Planck Institute for Biogeochemistry, Hans-Knöll Str. 10, 07745 Jena, Germany

${ }^{2}$ International Max Planck Research School (IMPRS) for Global Biogeochemical Cycles, Jena, Germany

\section{Correspondence: Lin Yu (lyu@bgc-jena.mpg.de)}

This appendix includes a detailed description of the model with equations and tables of parameter values.

\section{S1 The SOM cycle}

The model represents different soil organic pools (woody $(w l)$, polymeric (poly), and soluable (sol) litter, as well as dissolved organic matter (DOM, dom), microbial biomass ( $m i c)$, microbial residue (res), mineral-associated DOM (aDom), and

mineral-associated microbial residue $(a R e s))$, and the dynamics of them $\left(X=\mathrm{C}, \mathrm{N}, \mathrm{P},{ }^{13} \mathrm{C},{ }^{14} \mathrm{C},{ }^{15} \mathrm{~N}\right)$ are described in general as:

$$
\begin{aligned}
& \frac{\partial}{\partial t} X_{w l}=\sum\left(f_{v p \rightarrow w l} F_{L_{v p}}\right)-\frac{X_{w l}}{\tau_{w l}}-\frac{\partial}{\partial z}\left(D_{b} \frac{\partial X_{w l}}{\partial z}\right)-\frac{\partial\left(\omega \cdot X_{w l_{s l>1}}\right)}{\partial z} \\
& \frac{\partial}{\partial t} X_{s o l}=\sum\left(f_{v p \rightarrow s o l} F_{L_{v p}}\right)-\frac{X_{s o l}}{\tau_{s o l}}-\frac{\partial}{\partial z}\left(D_{b} \frac{\partial X_{s o l}}{\partial z}\right)-\frac{\partial\left(\omega \cdot X_{s o l}\right)}{\partial z} \\
& \frac{\partial}{\partial t} X_{\text {poly }}=\sum\left(f_{v p \rightarrow \text { poly }} F_{L_{v p}}\right)+\eta_{w l \rightarrow \text { poly }} \frac{X_{w l}}{\tau_{w l}}-F_{\text {poly } \rightarrow \text { dom }}^{\text {depoly }} \\
& -\frac{\partial}{\partial z}\left(D_{b} \frac{\partial X_{\text {poly }}}{\partial z}\right)-\frac{\partial\left(\omega \cdot X_{\text {poly }}\right)}{\partial z} \\
& \frac{\partial}{\partial t} X_{\text {dom }}=\eta_{\text {sol } \rightarrow \text { dom }} \frac{X_{\text {sol }}}{\tau_{\text {sol }}}+F_{\text {poly } \rightarrow \text { dom }}^{\text {depoly }}+F_{\text {res } \rightarrow \text { dom }}^{\text {depoly }}-F_{\text {dom } \rightarrow \text { aDom }}^{\text {sorp }} \\
& -F_{d o m \rightarrow m i c}^{u p t}+\eta_{m i c \rightarrow d o m} \frac{X_{m i c}}{\tau_{m i c}}+\sigma_{\text {recycle }} \\
& -\frac{\partial v_{d o m} d o m}{\partial z}-\frac{\partial}{\partial z}\left(D_{b} \frac{\partial X_{d o m}}{\partial z}\right)-\frac{\partial\left(\omega \cdot X_{d o m}\right)}{\partial z} \\
& \frac{\partial}{\partial t} X_{\text {mic }}=F_{\text {mic }}^{\text {growth }}-\eta_{\text {mic } \rightarrow \text { dom }} \frac{X_{\text {mic }}}{\tau_{\text {mic }}}+\Phi_{\text {immobilisation }} \\
& -\frac{\partial}{\partial z}\left(D_{b} \frac{\partial X_{m i c}}{\partial z}\right)-\frac{\partial\left(\omega \cdot X_{m i c}\right)}{\partial z}
\end{aligned}
$$

25

$$
\begin{aligned}
\frac{\partial}{\partial t} X_{\text {res }} & =\eta_{\text {mic } \rightarrow \text { res }} \frac{X_{\text {mic }}}{\tau_{\text {mic }}}-F_{\text {res } \rightarrow \text { dom }}^{\text {depoly }}-F_{\text {res } \rightarrow \text { aRes }}^{\text {sorp }}-\sigma_{\text {recycle }} \\
& -\frac{\partial}{\partial z}\left(D_{b} \frac{\partial X_{\text {res }}}{\partial z}\right)-\frac{\partial\left(\omega \cdot X_{\text {res }}\right)}{\partial z} \\
\frac{\partial}{\partial t} X_{a D o m} & =F_{\text {res } \rightarrow a R e s}^{\text {sorp }}-\frac{\partial}{\partial z}\left(D_{b} \frac{\partial X_{a D o m}}{\partial z}\right)-\frac{\partial\left(\omega \cdot X_{a D o m}\right)}{\partial z} \\
\frac{\partial}{\partial t} X_{a \text { Res }} & =F_{\text {dom } \rightarrow a D o m}^{\text {sorp }}-\frac{\partial}{\partial z}\left(D_{b} \frac{\partial X_{a R e s}}{\partial z}\right)-\frac{\partial\left(\omega \cdot X_{a R e s}\right)}{\partial z}
\end{aligned}
$$


where $F_{L_{v p}}$ is the litterfall of the various plant tissue types, $f_{v p \rightarrow i}$ are the coefficients determining the partitioning of this litterfall to the litter pools (see Section S1.1), $\tau_{i}$ are temperature and moisture adjusted turnover times of the respective pools (X; i $=$ sol, wl, mic), $\eta_{i \rightarrow j}$ are the fractions of mass transfer from pool $i$ to $j$ (see Section S1.2), $F_{i \rightarrow j}^{Y}$ is the the flux rates of processes $Y$ (depoly: depolymerisation; upt: microbial uptake of DOM; sorp: sorption to mineral surface) from pool $i$ to $j$ (see

5 Section S1.4, S1.3 and S1.5), $F_{\text {mic }}^{\text {growth }}$ the microbial growth rate, $\sigma_{\text {recycle }}$ is the additional nutrients recycled to DOM when microbes decay, $\Phi_{\text {immobilisation }}$ is the immobilisation terms for $\mathrm{N}$ and $\mathrm{P}$, required to balance the microbial C:N:P stoichiometry (see Sect. S1.5). The $D_{b}$ is a prescribed diffusion constant for transfer of soil organic matter through bioturbation, and $\omega$ is the flux rate representing the advective transport of soil organic matter due to SOM accumulation/diminishing, where the aboveground woody litter is not subjective to this transport (see Section S3), and $\frac{\partial v_{d o m} d o m}{\partial z}$ is the percolation loss term given by the dom concentration and water mass flow between soil layers.

\section{S1.1 Partitioning of litterfall to litter pools}

Non-woody litterfall is partitioned to the soluable and polymeric litter according to the CENTURY approach (Parton et al., 1993). Litter from labile and reserve pools is assumed to enter the soluable pools, litter from sap- and heartwood enters the woody pool. The soluable fraction of litterfall from each vegetation pool $(v p$, i.e. leaves, fine and coarse roots, fruits and seed-bed) is determined as:

$$
f_{v p \rightarrow s o l, C}=f_{\text {sol, max }, C}-k_{s o l, C} \cdot L C_{v p} \frac{C_{v p}}{N_{v p}}
$$

where $f_{v p \rightarrow s o l, C}$ is constrained to positive solutions, $f_{s o l, \max , C}$ is the maximum fraction allocated to the soluable pool, $k_{s o l, C}$ a factor relating the soluable litter fraction to the lignin to nitrogen ratio, $L C_{v p}$ the tissue-specific fraction of the lignin content of that tissue type, and $\frac{C_{v p}}{N_{v p}}$ the $\mathrm{C}: \mathrm{N}$ ratio of litterfall from that tissue. The lignin content is assumed constant for all but the leaf tissues. For the latter, an empirical dependency between lignin content and specific leaf-area (sla) is used (White et al., 2000).

$$
L C_{\text {leaf }}=L C_{\text {leaf }, \text { max }}+k_{\text {leaf } 2 s l a} \cdot \text { sla }
$$

The remainder of litterfall is allocated to the polymeric pool. For $\mathrm{N}$ and $\mathrm{P}$, the partitioning assumes that the relative proportions of $\mathrm{C}: \mathrm{N}$ and $\mathrm{N}: \mathrm{P}$ are preserved in the partitioning according to:

$$
f_{v p \rightarrow s o l, X}=\frac{1}{1+\frac{1-f_{v p \rightarrow s o l, C}}{k_{s o l, v p, X} \cdot f_{v p \rightarrow s o l, C}}}
$$

\section{S1.2 Litter turnover}

Woody decomposition is assumed to be a two-stage process. The first step implies physical destabilisation and a first level of biochemical processing, which releases a constant fraction of carbon $\left(1-\eta_{C, w l \rightarrow \text { poly }}\right)$ to heterotrophic respiration. The remainder is assumed to enter the polymeric litter that further depolymerises into DOM. soluable litter decomposes with a similar two-stage process, where during the first step a fraction of carbon $\left(1-\eta_{C, s o l \rightarrow d o m}\right)$ is respired but the remainder directly enters the DOM pool, which is taken up by microbes.

The turnover times $\left(\tau_{i}^{\text {base }}\right)$ of the woody and soluable litter respond to soil temperature $\left(T_{\text {soil }}\right)$ and soil water content $(\Theta)$ as follows:

$$
\tau_{i}^{*}=\tau_{i}^{\text {base }} f\left(T_{\text {soil }}\right) g\left(\Theta_{\text {soil }}\right), \text { where }
$$

$$
\begin{aligned}
f\left(T_{\text {soil }}\right) & =e^{-\frac{E_{a, \text { depoly }}}{R}\left(\frac{1}{T_{\text {soil }}}-\frac{1}{T_{\text {ref }}^{T}}\right)} \\
g(\Theta) & =\frac{a f p s^{k 1_{\text {afps }}}}{k_{a f p s}+a f p s^{k 1_{\text {afps }}}}, \text { where } \\
\text { afps } & =\frac{\Theta_{f c}-\Theta_{\text {soil }}}{\Theta_{f c}}
\end{aligned}
$$


where $E_{a, \text { depoly }}$ is the activation energy of depolymerisation, $T_{r e f}^{\tau}$ is the reference temperature of the turnover rate, $k 1_{\text {afps }}$ and $k_{a f p s}$ are parameters, afps is the air filled pore space, and $\Theta_{\text {soil }}$ and $\Theta_{f c}$ are the absolute soil water content and soil water field capacity, respectively.

\section{S1.3 Depolymerisation}

5 The depolymerisation from polymeric litter or microbial residue to DOM (dom) are assumed to be enzyme-limited and described with "reverse Michaelis-Menten" kinetics ((Ahrens et al., 2015), (Schimel and Weintraub, 2003)).

$$
\begin{gathered}
F_{\text {poly } \rightarrow \text { dom }}^{\text {depoly }}=v_{\text {max }, \text { depoly }}^{\text {poly }}\left(T_{\text {soil }}, \Theta\right) \frac{X_{\text {mic }} E n z_{\text {frac }}^{\text {poly }}}{K_{m, \text { depoly }}\left(T_{\text {soil }}, \Theta\right)+X_{\text {mic }} E n z_{\text {frac }}^{\text {poly }}} X_{\text {poly }} \\
F_{\text {res } \rightarrow \text { dom }}^{\text {depoly }}= \\
K_{m a x, \text { depoly }}^{\text {res }}\left(T_{\text {soil }}, \Theta\right) \frac{X_{\text {mic }} E n z_{\text {frac }}^{\text {res }}}{K_{m, \text { depoly }}\left(T_{\text {soil }}, \Theta\right)+X_{\text {mic }} E n z_{\text {frac }}^{\text {res }}\left(T_{\text {soil }}, \Theta\right)} X_{\text {res }}, \text { where } \\
=K_{m, \text { depoly }} e^{-\frac{E a, h s c}{R}\left(\frac{1}{\left.T_{\text {soil }}-\frac{1}{T_{\text {ref }}^{\tau}}\right)} \cdot\left(\frac{\Theta}{\Theta_{f c}}\right)^{k_{\text {hsc }}}\right.}
\end{gathered}
$$

10 where $v_{\text {max, depoly }}^{X}$ is the maximum depolymerisation rate of pool $X$ (poly or $r e s$ ) and its temperature and moisture responses are the same as those of litter turnover (Eq.S5), $E n z_{\text {frac }}^{X}$ is the fraction of enzyme (see Sect.S1.5.2) which targets to depolymerise pool $X$, and $K_{m, \text { depoly }}\left(T_{\text {soil }}, \Theta\right)$ is the temperature and moisture corrected, microbial biomass scaled, half-saturation enzyme concentration of depolymerisation.

\section{S1.4 SOC sorption stabilisation}

15 The sorption of DOM and microbial residue to mineral soil surface is represented with dynamic Langmuir isotherm, modified from the COMISSION model (Ahrens et al., 2015).

$$
\begin{aligned}
F_{\text {dom } \rightarrow \text { aDom }}^{\text {sorp }} & =k_{\text {dom }}^{\text {ads }} X_{\text {dom }} f\left(T_{\text {soil }}, \Theta\right) Q_{\text {avail }}^{\text {org }}+k_{\text {dom }}^{\text {des }} f\left(T_{\text {soil }}, \Theta\right) X_{\text {aDom }} \\
F_{\text {res } \rightarrow \text { aRes }}^{\text {sorp }} & =k_{\text {res }}^{\text {ads }} X_{\text {res }} f\left(T_{\text {soil }}, \Theta\right) Q_{\text {avail }}^{\text {org }}+k_{\text {res }}^{\text {ads }} f\left(T_{\text {soil }}, \Theta\right) X_{a R e s}, \text { where } \\
f\left(T_{\text {soil }}, \Theta\right) & =e^{-\frac{E a, \text { sorption }}{R}\left(\frac{1}{T_{\text {soil }}}-\frac{1}{T_{\text {ref }}}\right)} \cdot \frac{\Theta}{d z} \\
Q_{\text {avail }}^{\text {org }} & =Q_{\text {max }}^{\text {org }}-X_{\text {aDom }}-X_{\text {aRes }} \\
Q_{\text {max }}^{\text {org }} & =q_{\text {max }, \text { mineral }}^{\text {org }} \cdot(\text { Silt }+ \text { Clay }) \rho_{\text {soil }} V_{\text {mineral }}^{\text {frac }}
\end{aligned}
$$

where $k_{X}^{a d s}$ and $k_{X}^{\text {des }}$ are the adsorption rate and desorption rate between $X$ (dom or res) and its mineral-associated form (aDom or aRes), respectively, $d z$ is the soil depth, and Silt and Clay are the silt and clay content in weight fraction. It is assumed that the two substrates share the same sorption sites, which is represented by the maximum sorption capacity of organic matter $Q_{a v a i l}^{\text {org }}$ and it is calculated based on the weight and sorption capacity of fine soil, $q_{\text {max }}^{\text {org }}$ mineral, following COMISSION (Ahrens et al., In prep.).

\section{S1.5 Microbial growth and decay}

In JSM, the growth of microbial biomass $\left(F_{\text {mic }}^{\text {growth }}\right)$ depends on three factors: i) the uptake rate of DOM $\left(F_{d o m \rightarrow m i c}^{u p t}\right)$, ii) the

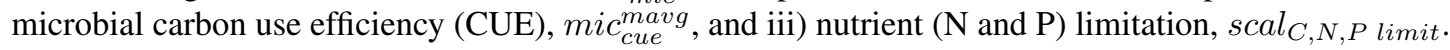

$$
\begin{aligned}
F_{\text {mic }}^{\text {growth }} & =m i c_{c u e}^{\text {mavg }} F_{d o m \rightarrow m i c}^{u p t} \\
F_{d o m \rightarrow m i c}^{u p t} & =\operatorname{MIN}\left(F_{d o m \rightarrow m i c}^{u p t^{*}}, \operatorname{scal}_{C, N, P \text { limit }} \cdot C_{d o m}\right)
\end{aligned}
$$


The potential uptake of DOM, $F_{d o m \rightarrow m i c}^{u p t^{*}}$, is constrained by the DOM concentration, meaning at high DOM concentration the uptake is limited by ability of microbes to assimilate DOM (Ahrens et al., 2015). It is described with "Michaelis-Menten" kinetics,

$$
F_{d o m \rightarrow m i c}^{u p t^{*}}=v_{m a x, u p t}^{\text {dom }}\left(T_{\text {soil }}, \Theta\right) C_{m i c} \frac{C_{d o m}}{K_{m, u p t}\left(T_{\text {soil }}, \Theta\right)+C_{d o m}}
$$

$5 \quad K_{m, u p t}\left(T_{\text {soil }}, \Theta\right)=K_{m, u p t} e^{-\frac{E a, h s c}{R}\left(\frac{1}{T_{\text {soil }}}-\frac{1}{T_{\text {ref }}^{\tau}}\right)} \cdot\left(\frac{\Theta}{\Theta_{f c}}\right)^{k_{h s c}}$

where $v_{\text {max. upt }}^{\text {dom }}$ is the maximum DOM uptake rate and has the same temperature and mositure responses as those of litter turnover (Eq.S5), $K_{m, \text { upt }}\left(T_{\text {soil }}, \Theta\right)$ is the temperature and moisture corrected half-saturation coefficient for DOM uptake.

Microbes response to the instantaneous conditions and associated fluxes to adapt their CUE. It is assumed in JSM that all the microbial adaptation has a process-specific lag time. Therefore, the microbial growth is calculated using the time-averaging microbial CUE, $m i c_{c u e}^{m a v g}$, which is a moving average of the current effective microbial CUE $\left(\operatorname{mic}_{c u e}^{e f f}\right)$ over a certain lag time.

$$
\begin{aligned}
& m i c_{\text {cue }}^{\text {mav }, \text { new }}=m i c_{\text {cue }}^{\text {mavg,old }} \cdot\left(1-\frac{d t}{\tau_{\text {mavg }}^{\text {mic }}}\right)+m i c_{\text {cue }}^{\text {eff }} \cdot \frac{d t}{\tau_{\text {mavg }}^{\text {mic }}} \\
& m i c_{c u e}^{e f f}=\operatorname{MAX}\left(\text { mic }_{\text {cue }}^{\text {min }}, \frac{F_{\text {mic }}^{\text {growth }}}{F_{d o m \rightarrow m i c}^{u p t^{*}}}\right) \\
& F_{\text {mic }}^{\text {growth }}=\operatorname{MIN}\left(F_{\text {mic }}^{\text {growth }, C^{*}}, F_{\text {mic }}^{\text {growth }, N^{*}}, F_{\text {mic }}^{\text {growth }, P^{*}}\right) \text {, where } \\
& F_{\text {mic }}^{\text {growth }, C^{*}}=\text { mic }_{\text {cue }}^{\text {max }} F_{d o m \rightarrow \text { mic }}^{u p t^{*}} \\
& F_{m i c}^{\text {growth }, N^{*}}=\left(\text { mic }_{n u e} \frac{F_{d o m \rightarrow m i c}^{u p t^{*}}}{\chi_{d o m}^{C: N}}+U_{N O_{3}, m i c}^{*}+U_{N H_{4}, m i c}^{*}\right) \chi_{m i c}^{C: N} \\
& F_{\text {mic }}^{\text {growth }, P^{*}}=\left(m i c_{p u e} \frac{F_{d o m \rightarrow m i c}^{u p t^{*}}}{\chi_{d o m}^{C: P}}+U_{P O_{4}, m i c}^{*}\right) \chi_{m i c}^{C: P}
\end{aligned}
$$

where $\tau_{\text {mavg }}^{\text {mic }}$ is the time span of the microbial CUE acclimation, $m i c_{c u e}^{m i n}$ is the theoretical minimal microbial CUE, $F_{m i c}^{\text {growth }, X^{*}}$ is the maximum potential microbial growth rate only considering the availability of element $X$, which takes account of the microbial nitrogen and phosphorus use efficiencies, $m i c_{n u e}$ and $m i c_{\text {pue }}{ }^{1}$, and the potential microbial uptake rate of nutrient, $U_{X, \text { mic }}^{*}\left(\mathrm{X}=\mathrm{NO}_{3}, \mathrm{NH}_{4}, \mathrm{PO}_{4}\right.$, see Sect.S2.2). The smallest growth potential determines the current effective CUE.

Given the time-averaging microbial CUE, the potential microbial growth only considering $\mathrm{C}$ is recalculated as $F_{\text {mic }}^{\text {growth, } C^{* *}}$. The uptake rate of DOM will be reduced if $F_{m i c}^{\text {growth }, C^{* *}}$ is bigger than $F_{m i c}^{\text {growth, } X^{*}}$, and the scaling factor $s c a l_{C, N, P \text { limit }}$ is calculated as,

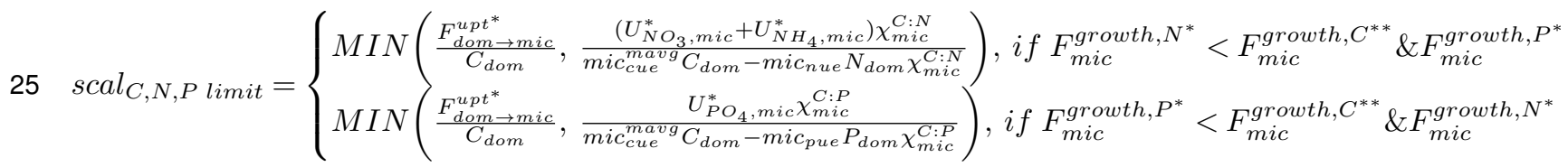

$$
\text { where, } F_{\text {mic }}^{\text {growth }, C^{* *}}=m i c_{\text {cue }}^{\text {mavg }} F_{d o m \rightarrow \text { mic }}^{\text {upt }}
$$

\footnotetext{
${ }^{1}$ In Eq.S10f and all the following cases, the microbial $\chi_{m i c}^{C: P}=\chi_{m i c}^{C: N} \cdot \chi_{m i c}^{N: P}$
} 


\section{S1.5.1 Microbial nutrient uptake, mineralisation, and microbial recycle}

Given the microbial growth and the C:N:P stoichiometry, the uptake of inorganic $\mathrm{N}$ and $\mathrm{P}, U_{X, m i c}$, is calculated as,

$$
\begin{aligned}
& U_{N_{4}, m i c}=U_{N H_{4}, m i c}^{*} s c a l_{N} \\
& U_{N_{3}, m i c}=U_{N O_{3}, m i c}^{*} s c a l_{N}
\end{aligned}
$$

$5 \quad U_{P_{4}, m i c}=U_{P_{4}, m_{i c}}^{*} s c a l_{P}$, where

$$
\operatorname{scal}_{P}=\frac{M A X\left(\frac{F_{m i c}^{\text {growth }, C}}{\chi_{m i c}^{C: P}}-m i c_{p u e} F_{m i c}^{u p t, P}, 0.0\right)}{U_{P O_{4}, m i c}^{*}}
$$

$$
\text { If } F_{\text {mic }}^{\text {growth }, C} \leq F_{\text {mic }}^{\text {growth, } P^{* *}}
$$

$$
\begin{aligned}
& F_{m i c}^{u p t, N}=m i c_{c u e}^{\text {mavg }} \frac{F_{d o m \rightarrow m i c}^{u p t}}{\chi_{d o m}^{C: N}} \\
& F_{m i c}^{u p t, P}=m i c_{c u e}^{\text {mavg }} \frac{F_{d o m \rightarrow m i c}^{u p t}}{\chi_{d o m}^{C: P}} \\
& F_{\text {mic }}^{\text {growth } N^{* *}}=\left(F_{\text {mic }}^{u p t, N}+U_{N_{3}, m_{i c}}^{*}+U_{N H_{4}, m i c}^{*}\right) \chi_{m i c}^{C: N} \\
& F_{\text {mic }}^{\text {growth }, P^{* *}}=\left(F_{\text {mic }}^{\text {upt }, P}+U_{P O_{4}, \text { mic }}^{*}\right) \chi_{\text {mic }}^{C: P}
\end{aligned}
$$

where $F_{m i c}^{g r o w t h, N^{* *}}$ and $F_{m i c}^{\text {growth }, P^{* *}}$ are the potential microbial growth only considering $\mathrm{N}$ or $\mathrm{P}$ availability given the timeaveraging CUE.

The effective microbial nutrient use efficiency $\left(m i c_{n u e}^{e f f}\right.$ and $\left.m i c_{p u e}^{e f f}\right)$ and the net mineralisation of $\mathrm{N}$ and $\mathrm{P}\left(\Phi_{\text {Nor } P}^{\text {net }}\right)$ are thus calculated as,

$$
\begin{aligned}
& m i c_{n u e}^{e f f}=\operatorname{MIN}\left(m i c_{n u e}, \frac{\frac{F_{m i c}^{\text {growth }, C}}{\chi_{m i c}^{C+N}}-U_{N H_{4}, m i c}-U_{N O_{3}, m i c}}{F_{m i c}^{u p t, N}}\right) \\
& m i c_{\text {pue }}^{\text {eff }}=\operatorname{MIN}\left(\text { mic }_{\text {pue }}, \frac{\frac{F_{m i c}^{\text {growth }, C}}{\chi_{m i c}^{C: P}}-U_{P O_{4}, m i c}}{F_{m i c}^{u p t, P}}\right)
\end{aligned}
$$

$\Phi_{N H_{4}}^{n e t}=\left(1-m i c_{n u e}^{e f f}\right) F_{m i c}^{u p t, N}-U_{N H_{4}, m i c}$

$$
\Phi_{\mathrm{NO}_{3}}^{\text {net }}=-U_{\mathrm{NO}_{3}, \mathrm{mic}}
$$

$\Phi_{P O_{4}}^{\text {net }}=\left(1-\right.$ mic $\left._{\text {pue }}^{\text {eff }}\right) F_{m i c}^{u p t, P}-U_{P_{4}, m i c}$

When microbes decay in JSM, there is a faction of the dead microbes $\left(\eta_{m i c \rightarrow d o m}\right)$ which directly recycles into the DOM
microbial cell wall has a lower nutrient content than plasma, it is assumed in JSM that $\mathrm{N}$ and $\mathrm{P}$ are more prone to be recycled into DOM when microbes decay, which is represented by $\sigma_{\text {recycle }}$ in Eq.S1.

$\sigma_{\text {recycle }}^{X}=\eta_{\text {mic } \rightarrow \text { res }} \frac{X_{\text {mic }}}{\tau_{\text {mic }}} \eta_{\text {res } \rightarrow \text { dom }}^{X}$ 
where $X$ represents $\mathrm{N}$ or $\mathrm{P}$, and $\eta_{r e s \rightarrow d o m}^{X}$ is the fraction of $\mathrm{X}$ that is recycled from newly formed res to dom during microbial decay.

\section{S1.5.2 Enzyme allocation in depolymerisation}

The enzyme allocation to polymeric litter and microbial residue is presented with the steady state of the Revenue strategy in the SEAM model (Wutzler et al., 2017), assuming that the microbial community adapts in a way that the fraction of enzyme allocation is proportional to its revenue (return-investment rate) of the limiting elements $(\mathrm{C}, \mathrm{N}$, or $\mathrm{P})$.

$$
\begin{aligned}
& \alpha_{\text {poly }}^{X}=\frac{R e v_{\text {poly }}^{X}}{R e v_{\text {poly }}^{X}+\operatorname{Rev} v_{\text {res }}^{X}} \\
& \alpha_{\text {res }}^{X}=\frac{\operatorname{Rev}_{\text {res }}^{X}}{R e v_{\text {poly }}^{X}+\operatorname{Rev}_{\text {res }}^{X}} \text {, where } \\
& \operatorname{Rev}_{\text {poly }}^{X}=\frac{\text { return }}{\text { investment }}=\frac{v_{\text {max,depoly }}^{\text {poly }} \cdot \frac{\alpha_{\text {poly }}^{X} C_{m i c}}{K_{m, \text { depoly }}+\alpha_{\text {poly }}^{X} C_{m i c}} \cdot X_{\text {poly }}}{\alpha_{\text {poly }}^{X} C_{m i c}} \\
& =\frac{v_{\text {max }, \text { depoly }}^{\text {poly }}}{K_{m, \text { depoly }}+\alpha_{\text {poly }}^{X} C_{m i c}} X_{\text {poly }} \\
& R e v_{\text {res }}^{X}=\frac{v_{m a x, \text { depoly }}^{\text {res }}}{K_{m, \text { depoly }}+\alpha_{r e s}^{X} C_{m i c}} X_{\text {res }} \text {, and } \\
& \alpha_{\text {poly }}^{X}+\alpha_{\text {res }}^{X}=1
\end{aligned}
$$

where $\alpha_{Y}^{X}$ is the potential enzyme allocation fraction to $Y$ (poly or res) based on the revenues of element $X(\mathrm{C}, \mathrm{N}$, or $\mathrm{P})$, and $\operatorname{Rev}_{y}^{X}$ is the revenue of element $X$ from source $y$ and is defined as the production of $X$ divided by the potential allocation of enzyme. In JSM the enzyme levels are not explicitly represented, thus a steady state assumption is made: the production and turnover of the enzyme is in equilibrium therefore the enzyme is always linear with the microbial biomass. we could get the analytical solution of the potential enzyme allocation fractions by rearranging Eq.S15,

$$
\begin{aligned}
& \frac{\alpha_{\text {poly }}^{X}}{\alpha_{\text {res }}^{X}}=\frac{\operatorname{Rev}_{\text {poly }}^{X}}{\operatorname{Rev} v_{\text {res }}^{X}} \Longrightarrow \\
& \frac{v_{m a x, \text { depoly }}^{\text {poly }} X_{\text {poly }}}{v_{\text {max }, \text { depoly }}^{\text {res }} X_{\text {res }}}=\frac{\alpha_{\text {poly }}^{X}}{1-\alpha_{\text {poly }}^{X}} \frac{K_{m, \text { depoly }}+\alpha_{\text {poly }}^{X} C_{m i c}}{K_{m, \text { depoly }}+\left(1-\alpha_{\text {poly }}^{X}\right) C_{m i c}} \Longrightarrow \\
& \alpha_{\text {poly }}^{X}=\frac{d_{\text {poly }} K_{m, \text { depoly }}+2 d_{\text {poly }} C_{m i c}+d_{\text {res }} K_{m, \text { depoly }}-\sqrt{D}}{2 C_{\text {mic }}\left(d_{\text {poly }}-d_{\text {res }}\right)}, \text { where } \\
& d_{\text {poly }}=v_{\text {max }, \text { depoly }}^{\text {poly }} X_{\text {poly }} \\
& d_{\text {res }}=v_{\text {max }, \text { depoly }}^{\text {res }} X_{\text {res }} \\
& D=4 d_{\text {poly }} d_{\text {res }} C_{\text {mic }}^{2}+8 d_{\text {poly }} d_{\text {res }} C_{m i c} K_{m, \text { depoly }}+K_{m, \text { depoly }}^{2} d_{\text {poly }}^{2} \\
& +2 d_{\text {poly }} d_{\text {res }} K_{m, \text { depoly }}^{2}+K_{m, \text { depoly }}^{2} d_{\text {res }}^{2}
\end{aligned}
$$

25 It is assumed that the microbial community would acclimate gradually to allocate the enzyme to optimize the utilisation of the most limiting element of depolymerisation, which is determined similarly as that in microbial growth (Eq.S10) except that the uptake of inorganic nutrients are not considered. 


$$
\begin{aligned}
E n z_{\text {frac }}^{\text {poly,new }} & =E n z_{\text {frac }}^{\text {poly }, \text { old }} \cdot\left(1-\frac{d t}{\tau_{\text {mavg }}^{\text {enzyme }}}\right)+\alpha_{\text {poly,mavg }}^{X, \text { new }} \cdot \frac{d t}{\tau_{\text {mavg }}^{\text {enzyme }}}, \text { where } \\
\alpha_{\text {poly,mavg }}^{X, \text { new }} & =\alpha_{\text {poly,mavg }}^{X, \text { old }} \cdot\left(1-\frac{d t}{\tau_{\text {mavg }}^{\text {enzyme }}}\right)+\alpha_{\text {poly }}^{X} \cdot \frac{d t}{\tau_{\text {mavg }}^{\text {enzye }}}
\end{aligned}
$$

and the most limiting element $\mathrm{X}$ is determined as

$$
\begin{aligned}
& \operatorname{MIN}\left(\left(F_{\text {poly } \rightarrow \text { dom }}^{\text {depoly }}+F_{\text {res } \rightarrow \text { dom }}^{\text {depoly }}\right) \cdot \text { mic }_{\text {cue }}^{\text {mavg }},\right. \\
& \left(\frac{F_{\text {poly } \rightarrow \text { dom }}^{\text {depoly }}}{\chi_{\text {poly }}^{C: N}}+\frac{F_{\text {res } \rightarrow \text { dom }}^{\text {depoly }}}{\chi_{\text {res }}^{C: N}}\right) \cdot m i c_{\text {nue }}^{\text {mavg }} \chi_{\text {mic }}^{C: N}, \\
& \left.\left(\frac{F_{\text {poly } \rightarrow \text { dom }}^{\text {depoly }}}{\chi_{\text {poly }}^{C: P}}+\frac{F_{\text {res } \rightarrow \text { dom }}^{\text {depoly }}}{\chi_{\text {res }}^{\text {C:P }}}\right) \cdot m i c_{\text {pue }}^{\text {mavg }} \chi_{\text {mic }}^{C: P}\right)
\end{aligned}
$$

where $\tau_{\text {mavg }}^{\text {enzyme }}$ is the time span of enzyme allocation acclimation, and $m i c_{n u e}^{\text {mavg }}$ and $m i c_{p u e}^{\text {mavg }}$ are the time averaging microbial $\mathrm{N}$ and $\mathrm{P}$ use efficiency, which is calculated similarly as $m i c_{c u e}^{\operatorname{mavg}}$ in Eq.S10.

\section{S2 Inorganic nutrient cycles}

In JSM, the net mineralisation and plant uptake of $\mathrm{NH}_{4}$ and $\mathrm{NO}_{3}$ are represented next to transport process. The dynamics of inorganic nitrogen are described as:

$$
\begin{aligned}
\frac{\partial}{\partial t} N H_{4} & =F_{\text {dep }, N H_{4}}-U_{N H_{4}, \text { plant }}+\Phi_{N H_{4}}^{n e t} \\
& -\frac{\partial}{\partial z}\left(D_{b} \frac{\partial N H_{4}}{\partial z}\right)-\frac{\partial\left(\omega \cdot N H_{4}\right)}{\partial z}-\frac{\partial v_{N H_{4}} N H_{4}}{\partial z} \\
\frac{\partial}{\partial t} N O_{3} & =F_{d e p, N O_{3}}-U_{N O_{3}, p l a n t}+\Phi_{N O_{3}}^{n e t} \\
& -\frac{\partial}{\partial z}\left(D_{b} \frac{\partial N O_{3}}{\partial z}\right)-\frac{\partial\left(\omega \cdot N O_{3}\right)}{\partial z}-\frac{\partial v_{N O_{3}} N O_{3}}{\partial z}
\end{aligned}
$$

15 where $U$ are the uptake rates of plants and microbes (see Section S2.2); the $F_{d e p, X}$ are the atmospheric deposition fluxes; $\frac{\partial v_{x} X}{\partial z}, \frac{\partial}{\partial z}\left(D_{b} \frac{\partial X}{\partial z}\right)$, and $\frac{\partial(\omega \cdot X)}{\partial z}$ are vertical transport terms due to percolation loss, bioturbation, and SOM accumulation/diminishing, respectively (see Sect.S3). 
The inorganic phosphorus cycle is mostly based on that of the QUINCY model (Thum et al., 2019) with modifications due to microbial interactions. The dynamics of inorganic phosphorus are described as:

$$
\begin{aligned}
& \frac{\partial}{\partial t} \mathrm{PO}_{4}=F_{\text {dep }, \mathrm{PO}_{4}}+F_{\text {weath }, \mathrm{PO}_{4}}+F_{\text {biomin }, \mathrm{PO}_{4}} \\
& \text { - } U_{\text {plant }, P O_{4}}-F_{\text {adsorp }, P_{4}}+\Phi_{P_{4}}^{\text {net }} \\
& -\frac{\partial}{\partial z}\left(D_{b} \frac{\partial P O_{4}}{\partial z}\right)-\frac{\partial\left(\omega \cdot P O_{4}\right)}{\partial z}-\frac{\partial v_{P O_{4}} P O_{4}}{\partial z} \\
& 5 \quad \frac{\partial}{\partial t} P_{l a b}=F_{a d s o r p, P O_{4}}-F_{a b s o r b, P O_{4}}-\frac{\partial\left(\omega \cdot P_{l a b}\right)}{\partial z} \\
& \frac{\partial}{\partial t} P_{\text {sorb }}=F_{\text {absorb }, P O_{4}}-F_{\text {occlusion }, P O_{4}}-\frac{\partial\left(\omega \cdot P_{\text {sorb }}\right)}{\partial z} \\
& \frac{\partial}{\partial t} P_{o c l}=F_{o c c l u s i o n, P O_{4}}-\frac{\partial\left(\omega \cdot P_{o c l}\right)}{\partial z} \\
& \frac{\partial}{\partial t} P_{\text {primary }}=-F_{\text {weath }, P O_{4}}-\frac{\partial\left(\omega \cdot P_{\text {primary }}\right)}{\partial z}
\end{aligned}
$$

where $P_{l a b}, P_{\text {sorb }}, P_{o c l}$, and $P_{\text {primary }}$ are adsorbed, absorbed, occluded, and primary P, respectively; the $F_{\text {dep }, P O_{4}}, F_{\text {weath, } P O_{4}}$,

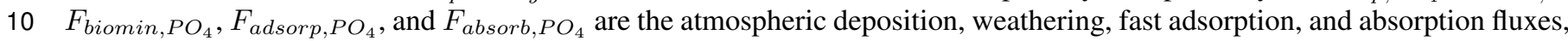
respectively (see Section $\mathrm{S} 2.1$ ).

\section{S2.1 Phosphorus weathering, biomineralisation and absorption}

Weathering is assumed to be driven by root and microbial exudation, and modified from Wang et al. (2010) as:

$$
\begin{gathered}
F_{\text {weath }, P O_{4}}=f\left(T_{\text {soil }}, \Theta\right) \frac{C_{\text {exu }}}{K_{m, \text { weath }}+C_{\text {enz }}} k_{\text {weath }} \rho_{\text {soil }}^{\text {cor }}, \text { where } \\
f\left(T_{\text {soil }}, \Theta\right)=e^{-\frac{E a, h s c}{R} \cdot\left(\frac{1}{T_{\text {soil }}}-\frac{1}{T_{\text {ref }}^{T}}\right)} \cdot\left(\frac{\Theta}{\Theta_{f c}}\right)^{3}, \\
C_{\text {exu }}=C_{\text {fine_root }} k_{\text {enz }, \text { root }}+C_{\text {mic }} k_{\text {enz } z \text { mic }}
\end{gathered}
$$

where $k_{\text {weath }}$ is the rate constant for weathering, $\rho_{\text {soil }}^{\text {cor }}$ is the soil bulk density corrected by SOM content, $C_{\text {exu }}$ represents an implicit general assemble of all exudation, analogous to the enzymatic abundance of fine roots and microbes $\left(k_{\text {enz,root }}\right.$ and $k_{e n z, m i c}$ ), and $K_{m, \text { weath }}$ is the half-saturation coefficient for weathering. The weathering rate decreases with soil depth as the fine root $\mathrm{C}$ and microbial biomass decreases and is modified by soil temperature and moisture.

The biomineralisation of $\mathrm{PO}_{4}$ is determined as an additional enzyme-catalysed cleavage of the $\mathrm{P}$ contained in the solid SOM pools $(\mathrm{X}=$ res, aRes, aDom $)$, modified by temperature and moisture modifiers, affected by the concentration of $\mathrm{PO}_{4}$ and enzyme abundance, and constrained by the C:P ratio of the organic pools:

$$
F_{\text {biomin }, P O_{4}}=v_{\text {max }, \text { biomin }} f\left(T_{\text {soil }}, \Theta\right) f\left(C_{\text {enz }} f\left(P O_{4}\right) f\left(\chi_{X}^{C: P}\right)\right. \text {, where }
$$

$$
\begin{aligned}
f\left(C_{\text {enz }}\right) & =\frac{C_{\text {enz }}}{K_{m, \text { biomin }}^{\text {exu }}+C_{\text {enz }}} \\
f\left(P O_{4}\right) & =\frac{K_{m, \text { biomin }}^{P O_{4}}}{K_{m, \text { biomin }}^{P O_{4}}+P O_{4}} \\
f\left(\chi_{X}^{C: P}\right) & =\frac{1}{1+\chi_{X}^{C: P} K_{m, \text { biomin }}^{C P}}
\end{aligned}
$$


where $K_{m, \text { biomin }}, K_{m, \text { biomin }}^{\mathrm{PO}_{4}}$ and $K_{m, P: C}$ are constants constraining the biomineralisation rate under low enzyme, high $\mathrm{PO}_{4}$ concentration, and high SOM C:P ratio, respectively, $\chi_{X}^{C: P}$ is the C:P ratio of the organic pools, and the temperature and moisture responses are calculated as those in Eq. S5.

$\mathrm{PO}_{4}$ absorption and occlusion are modelled as:

$5 \quad F_{\text {occlusion }, \mathrm{PO}_{4}}=k_{\text {ocl }} P_{\text {sorb }}$

$$
\begin{gathered}
F_{\text {desorp }, P O_{4}}=f\left(T_{\text {soil }}, E_{a, a b s}\right) k_{a b s} P_{\text {lab }}-f\left(T_{\text {soil }}, E_{a, \text { des }}\right) k_{s, \text { des }} P_{\text {sorb }}, \text { where } \\
f\left(T_{\text {soil }, E_{a}}\right)=e^{-\frac{E_{a}}{R} \cdot\left(\frac{1}{T_{\text {soil }}}-\frac{1}{T_{\text {ref }}^{\tau}}\right)}
\end{gathered}
$$

where $k_{o c l}, k_{a b s}$ and $k_{s, d e s}$ are the rate constants of occlusion, absorption and slow desorption, and $E_{a, a b s}$ and $E_{a, d e s}$ are the respective activation energies which equal to that of OM sorption (Eq.S7).

\section{S2.2 Nutrient acquisition}

It is assumed in the JSM model that the soluble forms of inorganic $\mathrm{NH}_{4}, \mathrm{NO}_{3}$, and $\mathrm{PO}_{4}$ are the only bio-available nutrients for plants and microbes, and specifically for $\mathrm{PO}_{4}$, the soluble inorganic form is assumed to be the only form that could be adsorbed by the mineral surfaces. The uptake of plants and microbes as well as the $\mathrm{PO}_{4}$ adsorption are all represented by the formations of consumer-substrate network using their full equilibrium chemistry approximations (ECA), following Tang and Riley (2013):

$$
\begin{aligned}
U_{X, y_{1}}^{*} & =f\left(T_{\text {soil }}, \Theta\right)_{y_{1}} v_{\text {max }, y_{1}}^{X} \frac{[X]}{K_{m, y_{1}}^{X}+[X]+E n z_{y_{1}}^{X}+K_{m, y_{1}}^{X} \frac{E n z_{y_{2}}^{X}}{K_{m, y_{2}}^{X}}+K_{m, y_{1}}^{X} \frac{E n z_{y_{3}}^{X}}{K_{m, y_{3}}}} \text {, where } \\
E n z_{\text {plant }}^{X} & =C_{\text {fine_root }} k_{\text {enz,root }}^{X} \\
E n z_{\text {mic }}^{X} & =C_{\text {mic }} k_{\text {enz }, \text { mic }}^{X}
\end{aligned}
$$

where $U_{X, y}^{*}$ is the potential acquisition rate of substrate $X\left(\mathrm{NH}_{4}, \mathrm{NO}_{3}\right.$, and $\left.\mathrm{PO}_{4}\right)$ through process $y$ (plant: plant uptake, mic: microbial uptake, or adsorp: adsorption). The maximum uptake rates $\left(v_{\max , y}^{X}\right)$ of plant and microbes are adopted from literature (see Table S1), while the maximum $\mathrm{PO}_{4}$ adsorption rate is calculated following Van der Zee et al. (1989); Enz $z_{y}^{X}$ represents the enzymatic capacity of $y$ to consume the substrate $X$ and it is assumed to be linear with the root biomass of plant, microbial biomass for microbe, and equals with the available sorption sites for mineral soil, and $k_{e n z, y}^{X}$ is the coefficient representing the transporters' abundance and capacity; the $[X]$ represents the total substrate concentration for all the relevant acquisition processes, and it equals the soluble inorganic concentration for $\mathrm{NH}_{4}$ and $\mathrm{NO}_{3}$, while for $\mathrm{PO}_{4}$ it is the sum of soluble and labile inorganic $\mathrm{P}$. The uptake rate of plants and microbes are influenced by temperature and moisture as that in Eq.S6. 
The potential acquisition rate will be down scaled if the sum of them exceed the size of the substrate pool. The actual microbial uptake rate also depends on the uptake demand of microbes (see Sect.S1.5). The actual adsorption rate are further calculated based on the assumption that the soluble inorganic P tend to equilibrate with the adsorbed P (see Sect.S2.2.1).

$U_{X, y_{1}}^{*}=U_{X, y_{1}}^{*} \cdot \frac{X}{\sum\left(U_{X, y}^{*}\right)}$ when $X<\sum\left(U_{X, y}^{*}\right)$

\section{$5 \quad$ S2.2.1 $\quad \mathrm{PO}_{4}$ adsorption equilibrium}

The adsorption $\left(F_{a d s o r p, P O_{4}}\right)$ flux from soil solution to the soil adsorption sites is calculated assuming constant Langmuir equilibrium (Barrow, 1978) between soluble and adsorbed P:

$$
\begin{aligned}
P O_{4} & =\frac{S_{\text {max }}^{P O_{4}} \cdot P O_{4}}{K_{S}+P O_{4}}, \text { where } \\
S_{\text {max }}^{P O_{4}} & =\Theta_{\text {soil }} \cdot\left(S_{\text {max }, \text { om }}^{P O_{4}} V_{\text {om }}^{\text {frac }} \rho_{\text {bulk }}^{\text {org }}+S_{\text {max }, \text { mineral }}^{P O_{4}} V_{\text {mineral }}^{\text {frac }} \rho_{\text {soil }}\right) \\
10 \quad K_{S} & =K_{S, \text { om }} V_{\text {om }}^{\text {frac }} \rho_{\text {bulk }}^{\text {org }}+K_{S, \text { mineral }} V_{\text {mineral }}^{\text {frac }} \rho_{\text {soil }}
\end{aligned}
$$

where $S_{\max }^{P O_{4}}$ and $K_{S}$ are the maximum sorption capacity, and the half-saturation concentration coefficient of the soil, and are both modified by soil moisture and SOM content; $V_{o m}^{\text {frac }}$ and $V_{\text {mineral }}^{\text {frac }}$ are volumetric fractiosn of organic matter and fine soil minerals, respectively. $S_{\text {max om }}^{P_{4}}$ and $S_{\text {max,mineral }}^{P O_{4}}$ are the maximum $\mathrm{PO}_{4}$ sorption capacity of pure organic matter and pure fine soil, respectively. $K_{S, o m}$ and $K_{S, \text { mineral }}$ are the half-saturation concentration coefficient of pure organic matter and 15 pure fine soil, respectively.

The Eq.S25 is solved analytically since $S_{\max }^{\mathrm{PO}_{4}}$ and $K_{S}$ are also changing with time.

$$
\begin{aligned}
P_{l a b}^{\prime} & =\frac{\left[P O_{4}\right]^{\prime}+S_{m a x}^{P O_{4}}+K_{S}-\sqrt{\left(\left[P O_{4}\right]^{\prime}+S_{m a x}^{P O_{4}}+K_{S}\right)^{2}-4 \cdot\left[P O_{4}\right]^{\prime} S_{\max }^{P O_{4}}}}{2} \\
P O_{4}^{\prime} & =\left[P O_{4}\right]^{\prime}-P_{l a b}, \text { where } \\
{\left[P O_{4}\right]^{\prime} } & =P_{l a b}+P O_{4}+\frac{\partial\left(P_{l a b}+P O_{4}\right)}{\partial t} \\
20 \frac{\partial\left(P_{l a b}+P O_{4}\right)}{\partial t} & =F_{\text {dep }, P O_{4}}+F_{\text {weath }, P O_{4}}+F_{b i o m i n, P O_{4}} \\
& -U_{\text {plant }, P O_{4}}-U_{m i c, P O_{4}}+\Phi_{P O_{4}}^{\text {net }} \\
& -\frac{\partial}{\partial z}\left(D_{b} \frac{\partial P O_{4}}{\partial z}\right)-\frac{\partial\left(\omega \cdot P O_{4}\right)}{\partial z}-\frac{\partial v_{P O_{4}} P O_{4}}{\partial z} \\
& -F_{a b s o r b, P O_{4}}-\frac{\partial\left(\omega \cdot P_{l a b}\right)}{\partial z}
\end{aligned}
$$

where the pools with apostrophe as superscript denote the size at the end of time step. 


\section{S3 Transport and bulk density correction}

In JSM the soil profile always starts from the top of the organic layer, therefore changes of SOM content would affect the layering of the soil profile, which is represented by an advective transport rate $\omega$, following COMISSION model Ahrens et al. (2015)

5

$$
\omega_{s l=n}=\frac{\sum_{s l=n}^{1} \Delta W_{O M_{s l}} \cdot d z_{s l}}{\rho_{\text {bulk }}^{\text {org }}} \text {, where }
$$

$\Delta W_{O M_{s l}}=\sum\left(C_{X_{s l}}^{\prime}-C_{X_{s l}}\right) \frac{M_{o l}}{1000 \cdot \operatorname{frac}_{O M}^{C}}$

where subscript $s l$ denotes the soil layer, $d z$ the layer depth, $\rho_{\text {bulk }}^{\text {org }}$ the bulk density of organic material; $\Delta W_{O M}$ is the change of total SOM weight which includes all the organic pools (NOTE: for the first layer woody litter is excluded), and is calculated based on the change of $\mathrm{C}$ content $\left(C_{X_{s l}}^{\prime}-C_{X_{s l}}\right)$, carbon molecular weight $\left(\mathrm{Mol}_{C}\right)$ and weight fraction of $\mathrm{C}$ in OM $\left(\mathrm{frac}_{O M}^{C}\right)$.

Not only all the organic pools and inorganic pools shift with the advective transport rate $\omega$ in JSM, but also the physical soil properties, such as soil texture, mineral soil density $\left(\rho_{\text {soil }}\right)$ and mineral soil volumetric fraction $\left(V_{\text {mineral }}^{\text {frac }}\right)$, shift with $\omega$ to ensure that the soil bulk density is properly corrected by the SOM content.

$\rho_{\text {soil }}^{\text {cor }}=V_{\text {mineral }}^{\text {frac }} \rho_{\text {soil }}+\left(1-V_{\text {mineral }}^{\text {frac }}\right) \rho_{\text {bulk }}^{\text {org }}$ 
Table S1. JSM parameters

\begin{tabular}{|c|c|c|c|c|c|}
\hline Symbol & Description & Value & Unit & Equation & Citation \\
\hline \multicolumn{6}{|c|}{ Litter partitioning and turnover } \\
\hline$f_{\text {sol }, \max , C}$ & maximum fraction of soluble litter formation & 0.85 & - & $\mathrm{S} 2$ & Parton et al. (1993) \\
\hline$k_{\text {sol }, C}$ & slope of soluble fraction with lignin to $\mathrm{N}$ ratio & 0.018 & - & S2 & Parton et al. (1993) \\
\hline$L C_{\text {coarse_root }}$ & lignin content of coarse roots & 0.8163248 & $m o l^{-1}$ & S2 & Thum et al. (2019) \\
\hline$L C_{w o o d y \_l i t t e r}$ & lignin content of woody litter & 0.8163248 & $m o l^{-1}$ & S2 & White et al. (2000) \\
\hline$L C_{\text {fruit }}$ & lignin content of seed bed & 0.2565592 & $m o l^{-1}$ & S2 & Thum et al. (2019) \\
\hline$L C_{\text {leaf, } \max }$ & maximum lignin content of leaves & 0.3440226 & $m o l^{-1}$ & S3 & White et al. (2000) \\
\hline$k_{l e a f 2 s l a}$ & slope of lignin to sla relationship & -0.4328854 & $m^{-2}$ & S3 & Parton et al. (1993) \\
\hline$k_{s o l, v p, N}$ & $\begin{array}{l}\text { proportionality factor controlling } \mathrm{C}: \mathrm{N} \text { of soluble vs. } \\
\text { polymeric pool }\end{array}$ & 5.0 & - & S4 & Parton et al. (1993) \\
\hline$k_{\text {sol }, v p, P}$ & $\begin{array}{l}\text { proportionality factor controlling C:P of soluble vs. } \\
\text { polymeric pool }\end{array}$ & 5.0 & - & S4 & Parton et al. (1993) \\
\hline$\tau_{\text {sol }}^{\text {base }}$ & turnover time of soluble litter & 0.033 & years & S5 & Parton et al. (1993) \\
\hline$\tau_{w l}^{b a s e}$ & turnover time of woody litter & 2.5 & years & S5 & Thum et al. (2019) \\
\hline$T_{r e f}^{\tau}$ & reference temperature for depolymerisation & 293.15 & $\mathrm{~K}$ & S5 & Wang et al. (2012) \\
\hline$E_{a, \text { depoly }}$ & activation energy for depolymerisation & 53000.0 & $\mathrm{Jmol}^{-1}$ & S5 & Ahrens et al. (In prep.) \\
\hline$k 1_{a f p s}$ & parameter for moisture response of litter turnover & 1.33 & - & S5 & This study \\
\hline$k_{a f p s}$ & parameter for moisture response of litter turnover & 0.001 & - & S5 & This study \\
\hline
\end{tabular}


Table S1. JSM parameters (ctnd.)

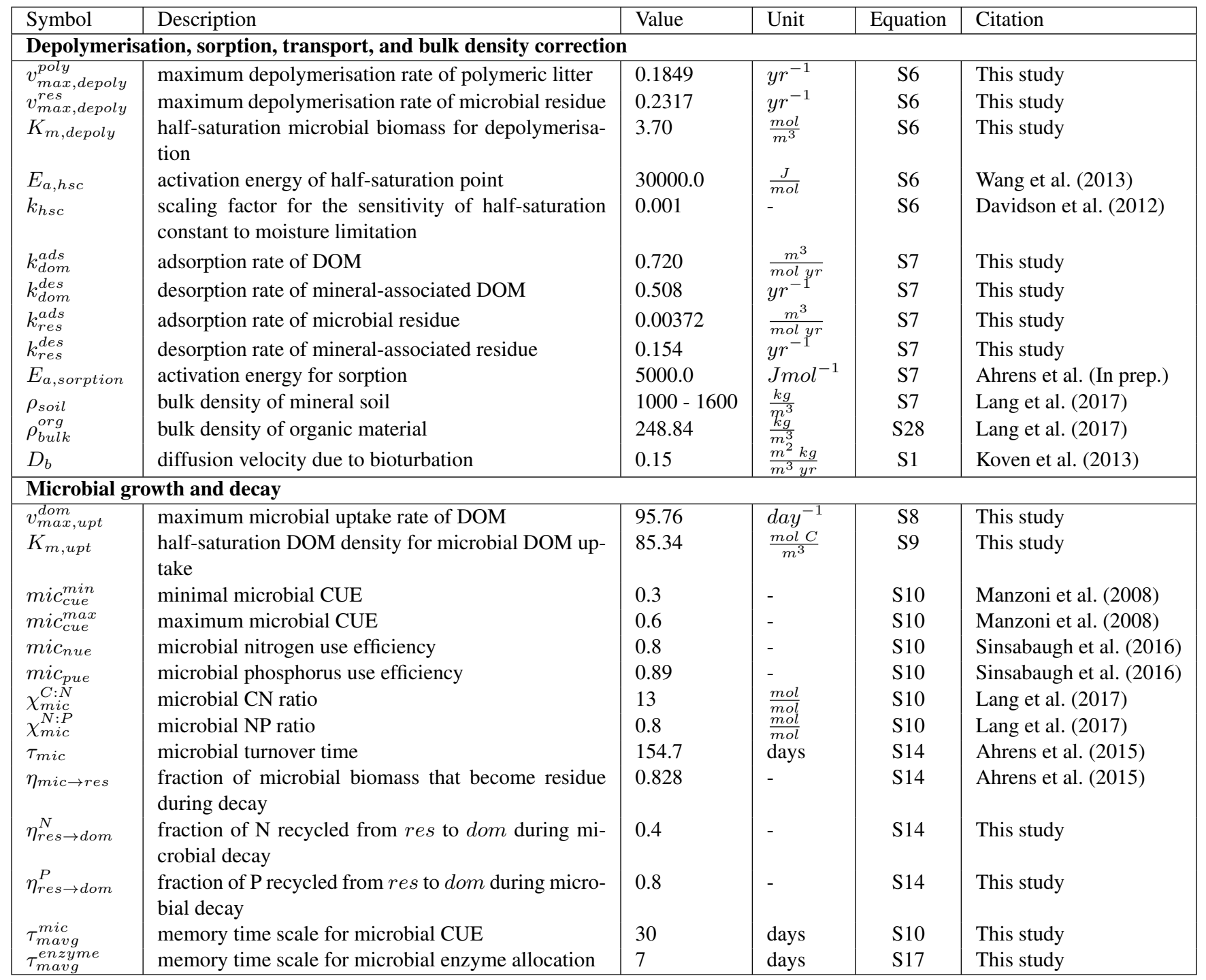


Table S1. JSM parameters (ctnd.)

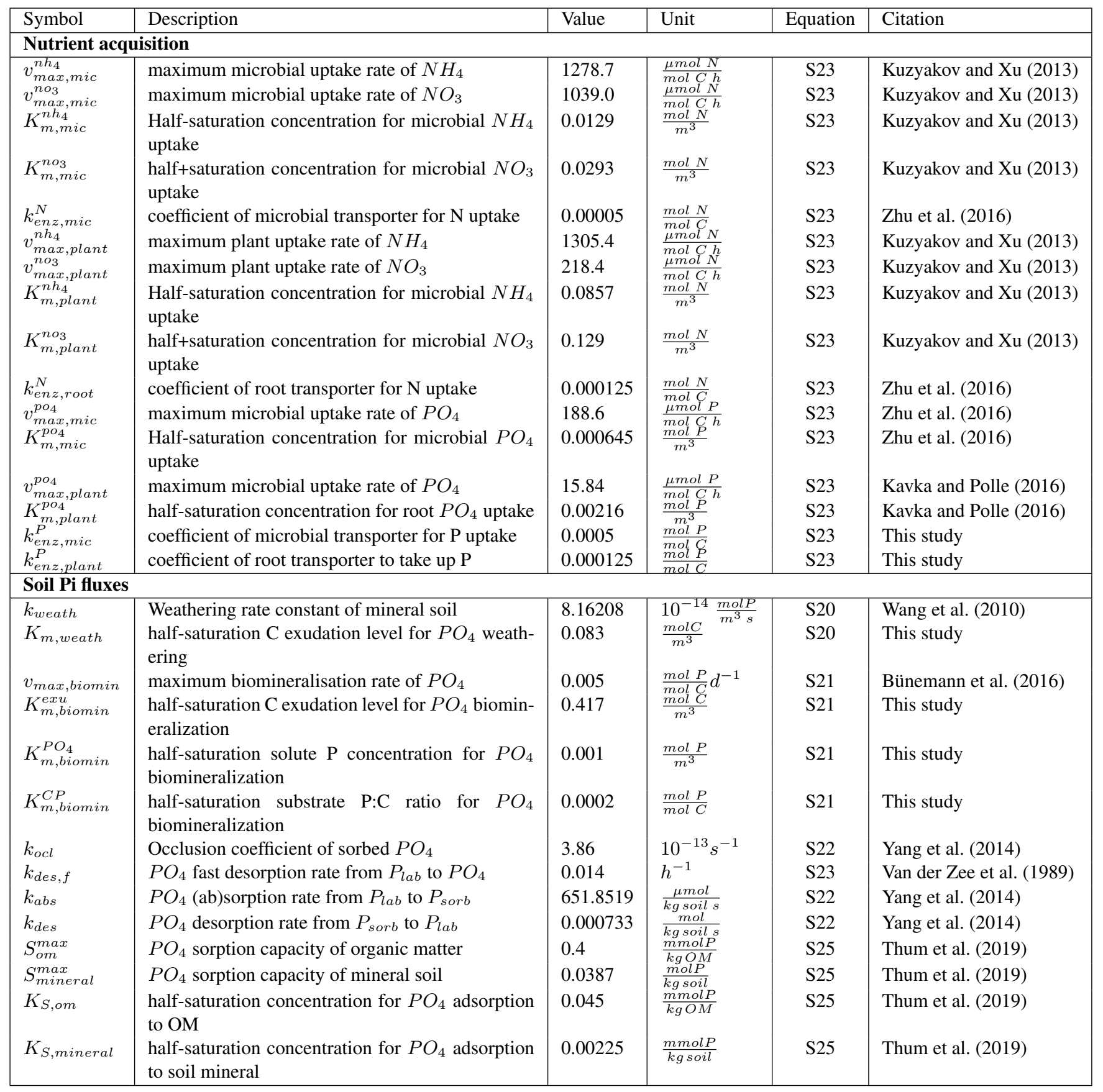


Table S2. Parameters for sensitivity analysis

\begin{tabular}{|c|c|}
\hline Parameter & Processes \\
\hline \multicolumn{2}{|c|}{ All the values vary between $80 \%$ and $120 \%$ of the default values in Table S1 } \\
\hline$k_{d o m}^{a d s}$ & OM sorption \\
\hline$k_{\text {dom }}^{\text {des }}$ & OM sorption \\
\hline$k_{\text {res }}^{a d s}$ & OM sorption \\
\hline$k_{\text {res }}^{\text {des }}$ & OM sorption \\
\hline$k_{\text {des }, f}$ & Nutrient acquisition \\
\hline$\chi_{m i c}^{C: N}$ & Microbial growth and decay \\
\hline$\chi_{m i c}^{N: P}$ & Microbial growth and decay \\
\hline mic $_{n u e}$ & Microbial growth and decay \\
\hline mic $c_{\text {pue }}$ & Microbial growth and decay \\
\hline $\operatorname{mic} c_{c u e}^{\min }$ & Microbial growth and decay \\
\hline$\eta_{C, w l \rightarrow p o l y}$ & Litter partitioning and turnover \\
\hline$\eta_{C, \text { sol } \rightarrow \text { dom }}$ & Litter partitioning and turnover \\
\hline$\tau_{m i c}$ & Microbial growth and decay \\
\hline$v_{m a x, u p t}^{d o m}$ & Microbial growth and decay \\
\hline$v_{\text {max } \text { depoly }}^{\text {poly }}$ & Depolymerisation \\
\hline$v_{\text {max }}^{\text {res depoly }}$ & Depolymerisation \\
\hline$\eta_{\text {res } \rightarrow \text { dom }}^{P}$ & Microbial growth and decay \\
\hline$\eta_{\text {res } \rightarrow \text { dom }}^{N}$ & Microbial growth and decay \\
\hline$v_{\max , \operatorname{mic}}^{n h_{4}}$ & Nutrient acquisition \\
\hline$v_{\max , \operatorname{mic}}^{\text {no3 }}$ & Nutrient acquisition \\
\hline$v_{\text {max }, \text { mic }}^{\text {pou }}$ & Nutrient acquisition \\
\hline$k_{e n z, m i c}^{N}$ & Nutrient acquisition \\
\hline$k_{\text {enz,mic }}^{P}$ & Nutrient acquisition \\
\hline$k_{\text {enz,root }}^{N}$ & Nutrient acquisition \\
\hline$k_{\text {enz,root }}^{P}$ & Nutrient acquisition \\
\hline$k_{w e a t h}$ & Soil Pi cycle \\
\hline$k_{o c l}$ & Soil Pi cycle \\
\hline$v_{\max , \text { biomin }}$ & Soil Pi cycle \\
\hline
\end{tabular}




\section{References}

Ahrens, B., Braakhekke, M. C., Guggenberger, G., Schrumpf, M., and Reichstein, M.: Contribution of sorption, DOC transport and microbial interactions to the $14 \mathrm{C}$ age of a soil organic carbon profile: Insights from a calibrated process model, Soil Biology and Biochemistry, 88 , 390-402, https://doi.org/10.1016/j.soilbio.2015.06.008, http://dx.doi.org/10.1016/j.soilbio.2015.06.008, 2015.

5 Ahrens, B., Reichstein, M., Guggenberger, G., and Schrumpf, M.: Towards reconciling radiocarbon and carbon in soils: the importance of modelling organo-mineral associations, In prep.

Barrow, N. J.: The description of phosphate adsorption curves, Journal of Soil Science, 29, 447-462, 1978.

Bünemann, E. K., Augstburger, S., and Frossard, E.: Dominance of either physicochemical or biological phosphorus cycling processes in temperate forest soils of contrasting phosphate availability, Soil Biology and Biochemistry, 101, 85-95, https://doi.org/10.1016/j.soilbio.2016.07.005, 2016.

Davidson, E. A., Samanta, S., Caramori, S. S., and Savage, K.: The Dual Arrhenius and Michaelis-Menten kinetics model for decomposition of soil organic matter at hourly to seasonal time scales, Glob. Change Biol., 18, 371-384, 2012.

Kavka, M. and Polle, A.: Phosphate uptake kinetics and tissue-specific transporter expression profiles in poplar (Populus $\times$ canescens) at different phosphorus availabilities, BMC Plant Biology, 16, 206, https://doi.org/10.1186/s12870-016-0892-3, https://doi.org/10.1186/ s12870-016-0892-3, 2016.

Koven, C. D., Riley, W. J., Subin, Z. M., Tang, J. Y., Torn, M. S., Collins, W. D., Bonan, G. B., Lawrence, D. M., and Swenson, S. C.: The effect of vertically resolved soil biogeochemistry and alternate soil $\mathrm{C}$ and $\mathrm{N}$ models on $\mathrm{C}$ dynamics of CLM4, Biogeosciences, 10, 7109-7131, 2013.

Kuzyakov, Y. and Xu, X.: Competition between roots and microorganisms for nitrogen: mechanisms and ecological relevance, New Phytologist, 198, 656-669, https://doi.org/doi:10.1111/nph.12235, https://nph.onlinelibrary.wiley.com/doi/abs/10.1111/nph.12235, 2013.

Lang, F., Krüger, J., Amelung, W., Willbold, S., Frossard, E., Bünemann, E. K., Bauhus, J., Nitschke, R., Kandeler, E., Marhan, S., Schulz, S., Bergkemper, F., Schloter, M., Luster, J., Guggisberg, F., Kaiser, K., Mikutta, R., Guggenberger, G., Polle, A., Pena, R., Prietzel, J., Rodionov, A., Talkner, U., Meesenburg, H., von Wilpert, K., Hölscher, A., Dietrich, H. P., and Chmara, I.: Soil phosphorus supply controls P nutrition strategies of beech forest ecosystems in Central Europe, Biogeochemistry, https://doi.org/10.1007/s10533-017-0375-0, 2017.

Manzoni, S., Porporato, A., and Schimel, J. P.: Soil heterogeneity in lumped mineralization-immobilization models, Soil Biology and Biochemistry, 40, 1137-1148, 2008.

Parton, W. J., Scurlock, J. M. O., Ojima, D. S., Gilmanov, T. G., Scholes, R. J., Schimmel, D. S., Kirchner, T., Menaut, J. C., Seastedt, T., Moya, E. G., Kamnalrut, A., and Kinyamario, J. I.: Observations and modelling of biomass and soil organic matter dynamics for the grassland biome worldwide, Global Biogeochemical Cycles, 7, 785-809, 1993.

30 Schimel, J. P. and Weintraub, M. N.: The implications of exoenzyme activity on microbial carbon and nitrogen limitation in soil: A theoretical model, Soil Biology and Biochemistry, 35, 549-563, https://doi.org/10.1016/S0038-0717(03)00015-4, http://linkinghub.elsevier.com/ retrieve/pii/S0038071703000154, 2003.

Sinsabaugh, R. L., Turner, B. L., Talbot, J. M., Waring, B. G., Powers, J. S., Kuske, C. R., Moorhead, D. L., and Follstad Shah, J. J.: Stoichiometry of microbial carbon use efficiency in soils, Ecological Monographs, 86, 172-189, https://doi.org/10.1890/15-2110.1, http: //dx.doi.org/10.1890/15-2110.1, 2016.

Tang, J. Y. and Riley, W. J.: A total quasi-steady-state formulation of substrate uptake kinetics in complex networks and an example application to microbial litter decomposition, Biogeosciences, 10, 8329-8351, https://doi.org/10.5194/bg-10-8329-2013, <GotoISI>://WOS: $000329054600033,2013$.

Thum, T., Caldararu, S., Engel, J., Kern, M., Pallandt, M., Yu, L., and Zaehle, S.: A new terrestrial ecosystem model with coupled carbon, nitrogen, and phosphorus cycles (QUINCY v1.0; revision 1610), https://projects.bgc-jena.mpg.de/QUINCY/browser/project-A/tags/tag1, 2019.

Van der Zee, S., Leus, F., and Louer, M.: Prediction of phosphate transport in small columns with an approximate sorption kinetics model, Water Resources Research, 25, 1353-1365, 1989.

Wang, G., Post, W. M., Mayes, M. A., Frerichs, J. T., and Sindhu, J.: Parameter estimation for models of ligninolytic and cellulolytic enzyme kinetics, Soil Biology and Biochemistry, 48, 28-38, https://doi.org/https://doi.org/10.1016/j.soilbio.2012.01.011, http: //www.sciencedirect.com/science/article/pii/S0038071712000247, 2012.

Wang, G., Post, W. M., and Mayes, M. A.: Development of microbial-enzyme-mediated decomposition model parameters through steadystate and dynamic analyses, Ecological Applications, 23, 255-272, https://doi.org/10.1890/12-0681.1, https://esajournals.onlinelibrary. wiley.com/doi/abs/10.1890/12-0681.1, 2013.

50 Wang, Y. P., Law, R. M., and Pak, B.: A global model of carbon, nitrogen and phosphorus cycles for the terrestrial biosphere, Biogeosciences, 7, 2261-2282, 2010. 
White, M. A., Thornton, P. E., Running, S., and Nemani, R.: Parameterization and Sensitivity Analysis of the BIOME-BGC Terrestrial Ecosystem Model: Net Primary Production Controls, Earth Interactions, 4, 1-55, 2000.

Wutzler, T., Zaehle, S., Schrumpf, M., Ahrens, B., and Reichstein, M.: Adaptation of microbial resource allocation affects modelled long term soil organic matter and nutrient cycling, Soil Biology and Biochemistry, 115, 322-336, https://doi.org/https://doi.org/10.1016/j.soilbio.2017.08.031,

http://www.sciencedirect.com/science/article/pii/S0038071717305680, 2017.

Yang, X., Thornton, P. E., Ricciuto, D. M., and Post, W. M.: The role of phosphorus dynamics in tropical forests - a modeling study using CLM-CNP, Biogeosciences, 11, 1667-1681, https://doi.org/10.5194/bg-11-1667-2014, https://www.biogeosciences.net/11/1667/2014/, 2014.

10 Zhu, Q., Riley, W. J., Tang, J., and Koven, C. D.: Multiple soil nutrient competition between plants, microbes, and mineral surfaces: model development, parameterization, and example applications in several tropical forests, Biogeosciences, 13, 341-363, https://doi.org/10.5194/bg-13-341-2016, 2016. 
(a) SOC

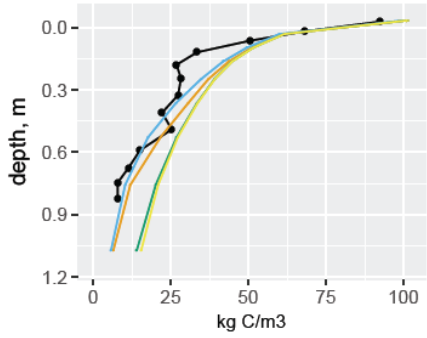

(d) Po-to-Pi ratio

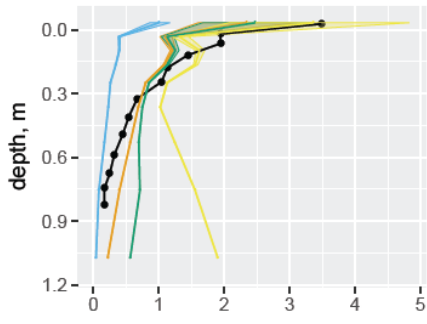

(g) Microbial C

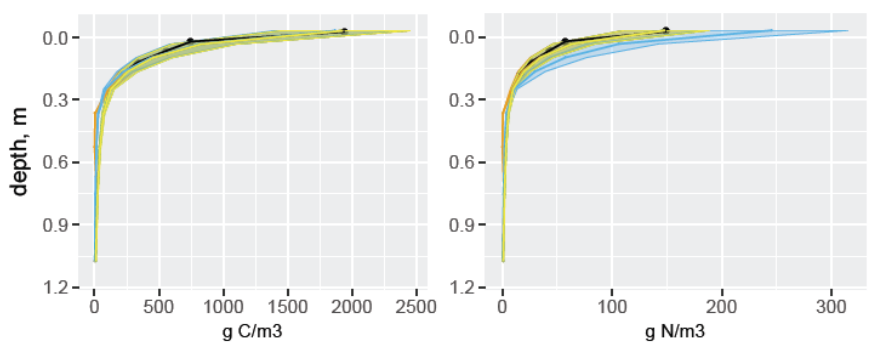

(b) SOM CN ratio

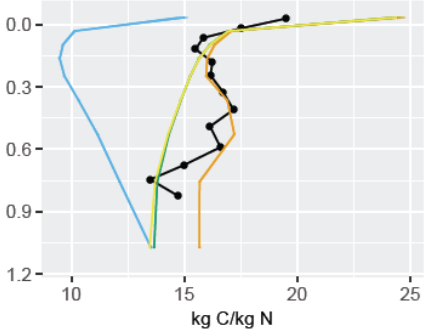

(e) 14C

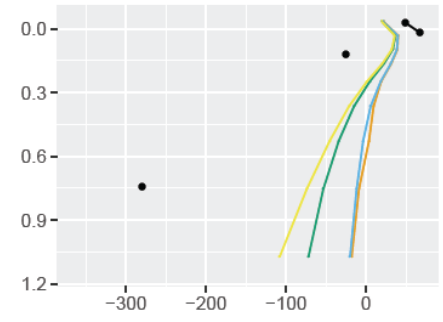

(h) Microbial N (c) SOM CP ratio

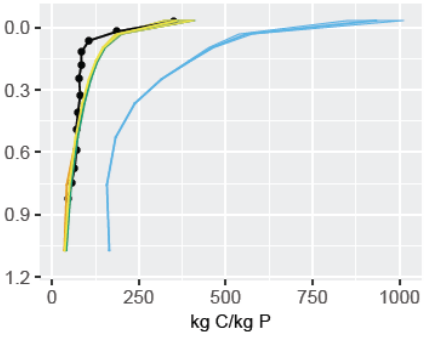

(f) Bulk density

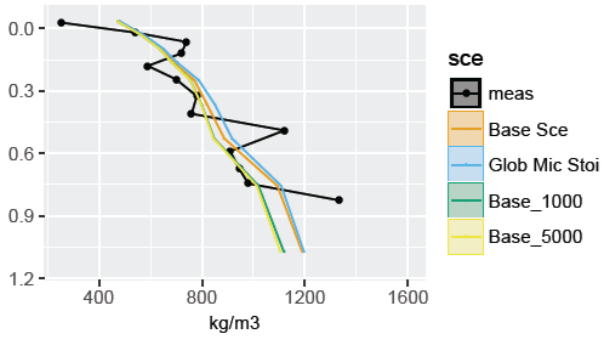

(i) Microbial $\mathbf{P}$

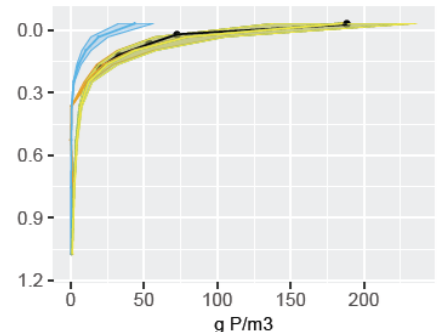

Figure S1. Simulated and observed (a) SOC content, (b) C:N ration in SOM, (c) C:P ratio in SOM, (d) organic P to inorganic P ratio in soil, microbial $\mathrm{C}, \mathrm{N}$, and $\mathrm{P}$ content ((e) to $(\mathrm{g}))$, and (h) soil bulk density at the study site up to $1 \mathrm{~m}$ soil depth. Black lines and dots: observations; Color lines and shades: simulated mean values and ranges of standard deviation by Base Scenario, the Global Microbial Stoichiometry (Glob. Mic. Stoi), and the extended base scenarios with simulation length of 1000 years (Base_1000) and 5000 years (Base_5000). The microbial $\mathrm{C}, \mathrm{N}$, and $\mathrm{P}$ are only measured in top $30 \mathrm{~cm}$ soil. Simulated means and standard deviations are calculated using data of the last 10 years from the model experiments. 

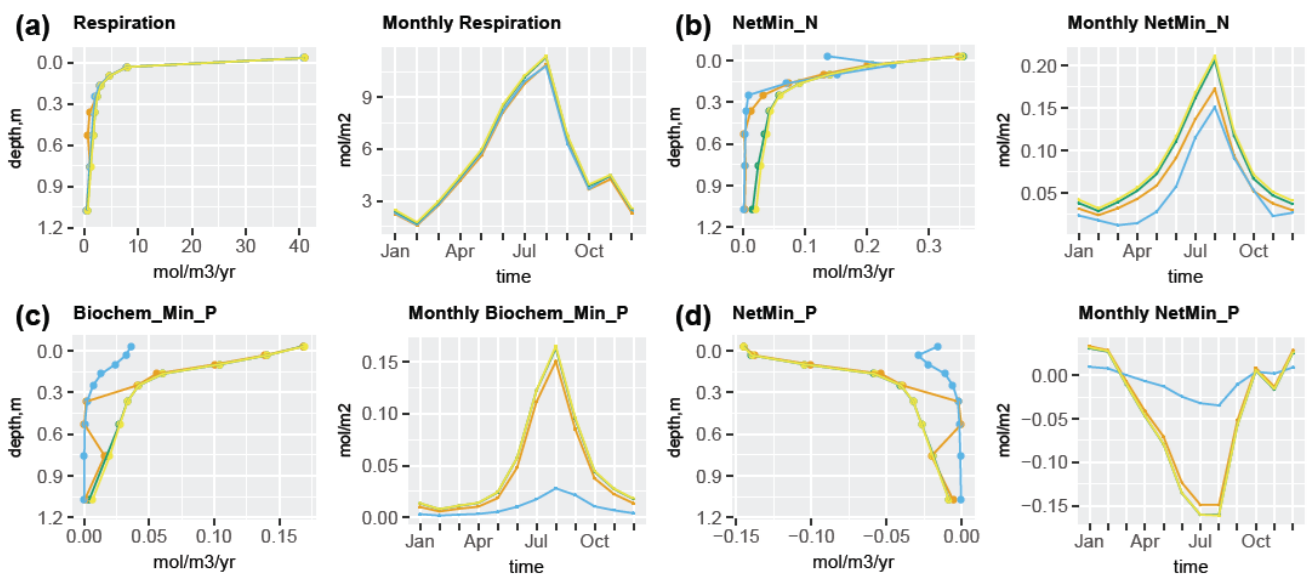

\section{(d) NetMin_P}
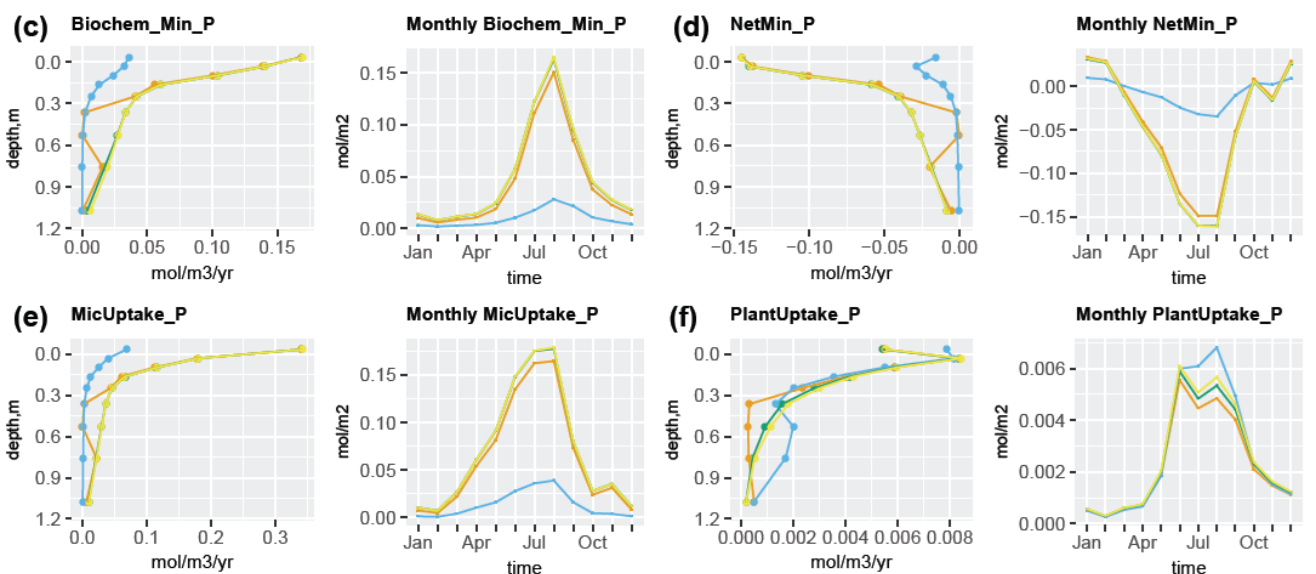

sce
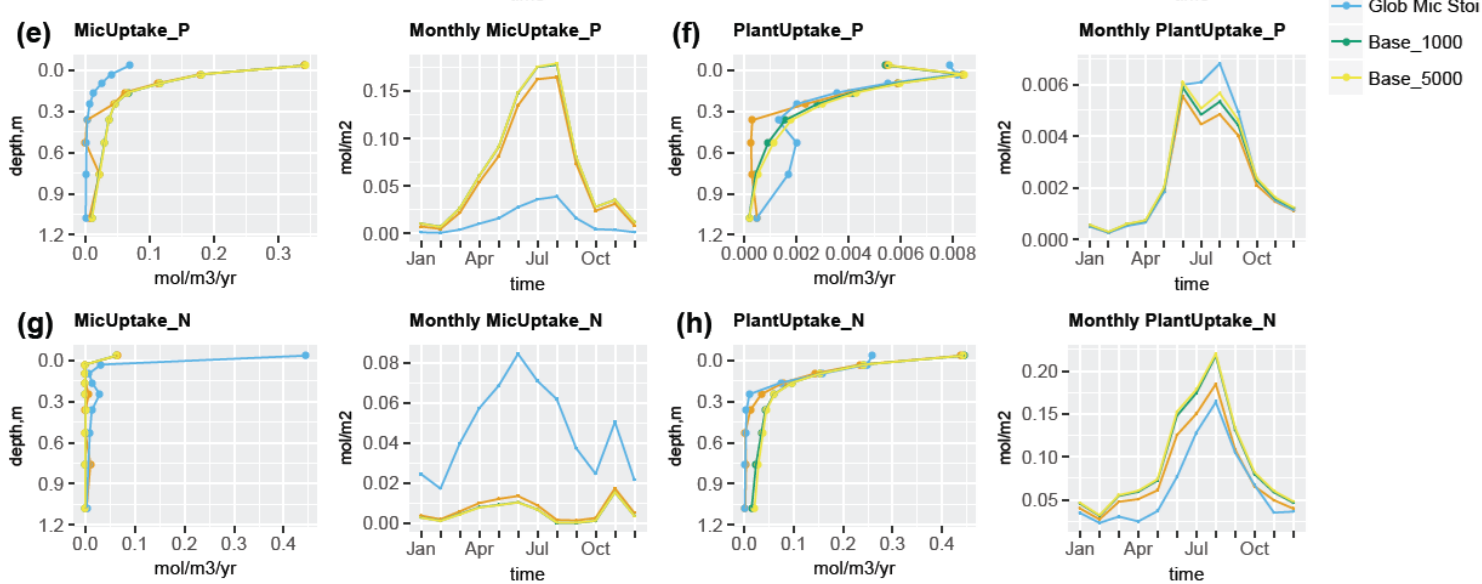

Figure S2. Simulated seasonal and vertical distribution of (a) respiration, (b) net N mineralisation, (c) biochemical P mineralisation, (d) net $\mathrm{P}$ mineralisation, (e) microbial inorganic $\mathrm{P}$ uptake, (f) plant $\mathrm{P}$ uptake, (g) microbial inorganic $\mathrm{N}$ uptake, and (h) plant $\mathrm{N}$ uptake at the study site up to $1 \mathrm{~m}$ soil depth. Points represent the mean values and error bars represent the standard deviations, both calculated using data of the last 10 years from the model experiments. 


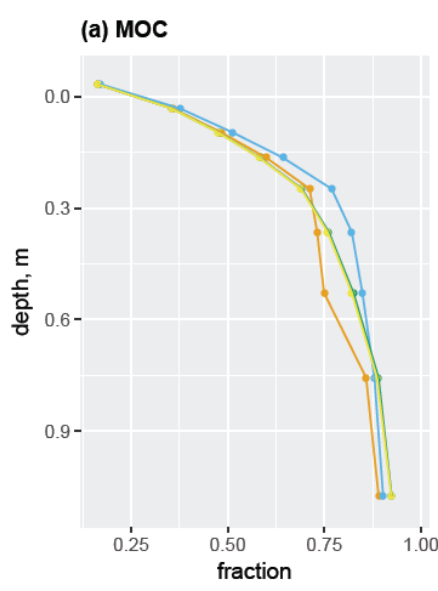

\section{(b) Litter}

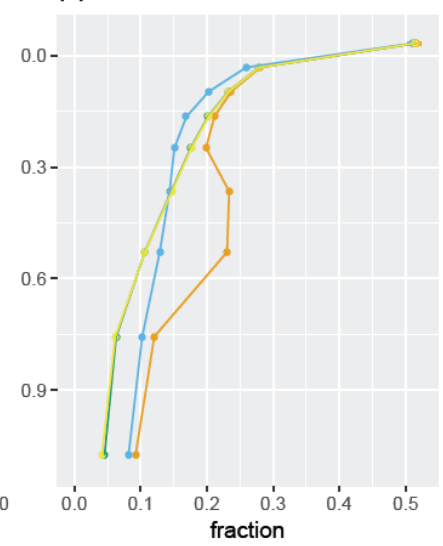

\section{C14_Litter}

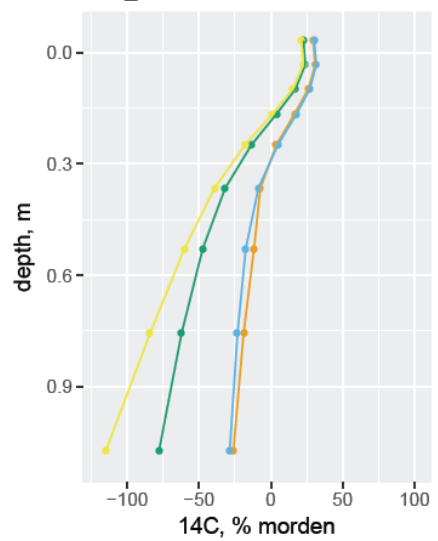

(c) Mic\&Residue

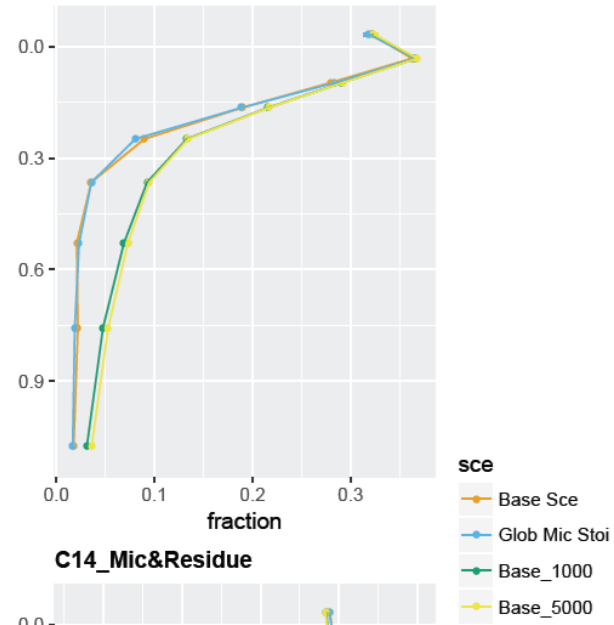

Figure S3. Simulated SOC fractions (upper panel) and their respective radiocarbon profiles (bottom panel) for up to $1 \mathrm{~m}$ soil depth. Column (a): mineral-associated carbon (MOC), including adsorbed DOM and adsorbed microbial residue; Column (b): litter, including woody, polymeric and soluble litter; Column (c): live and dead microbes. Data points are derived from the last 10 years' data of the model experiments. 
A

$\mathrm{N}$ budget in solution

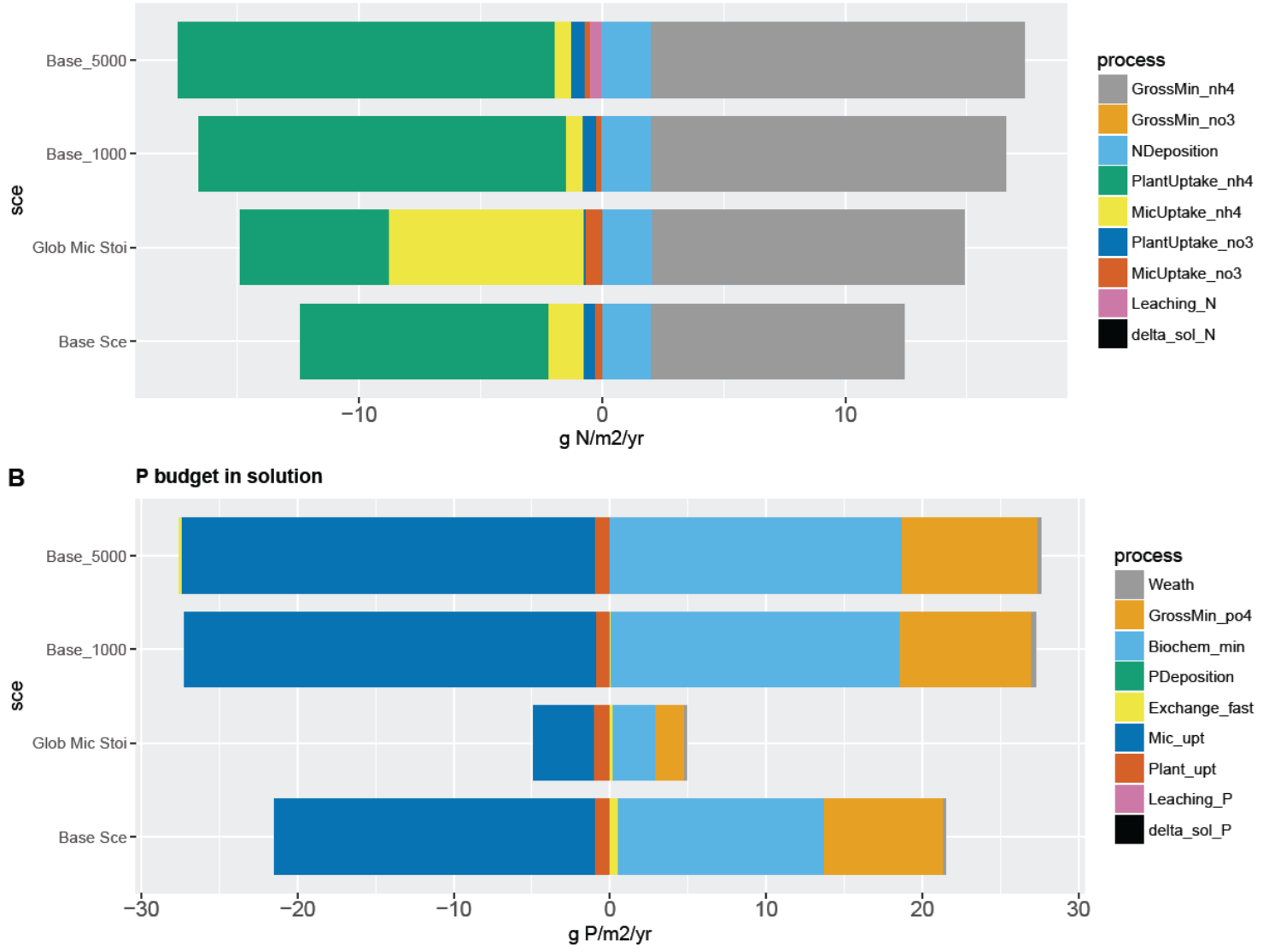

Figure S4. Simulated yearly budget of (A) nitrogen and (B) phosphorus in soil solution. In panel A, sourcing fluxes of $\mathrm{N}$ includes gross mineralisation of $\mathrm{NH}_{4}$ and $\mathrm{NO}_{3}, \mathrm{~N}$ deposition; sinking fluxes of $\mathrm{N}$ includes plant and microbial uptake of $\mathrm{NH}_{4}$, plant and microbial uptake of $\mathrm{NO}_{3}, \mathrm{~N}$ leaching (both inorganic and organic), and size change of soluble $\mathrm{N}$ (delta_sol_N). In panel B, sourcing fluxes of $\mathrm{P}$ includes weathering, gross mineralisation of $\mathrm{PO}_{4}$, biochemical mineralisation of $\mathrm{PO}_{4}, \mathrm{P}$ deposition; sinking fluxes of $\mathrm{P}$ includes adsorption (Exchange_fast), microbial and plant uptake, P leaching (both inorganic and organic), and size change of soluble P (delta_sol_P). The budget are calculated using data of the full simulation from the model experiments. 
(a) soc

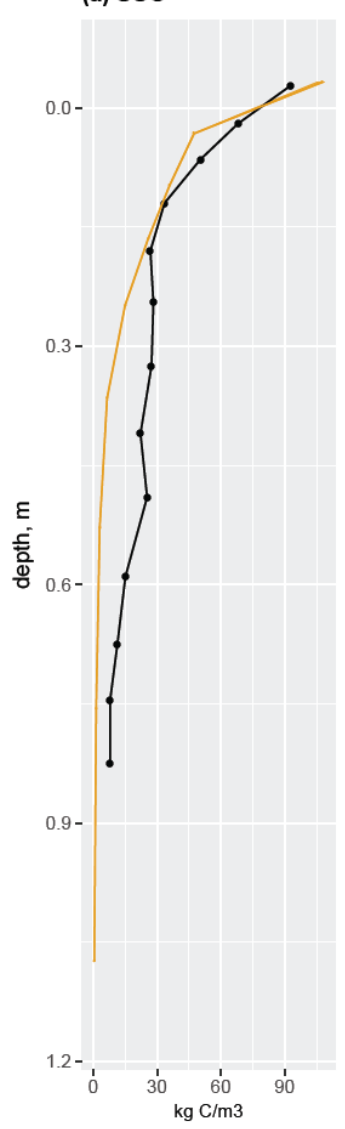

(b) SoM CN ratio

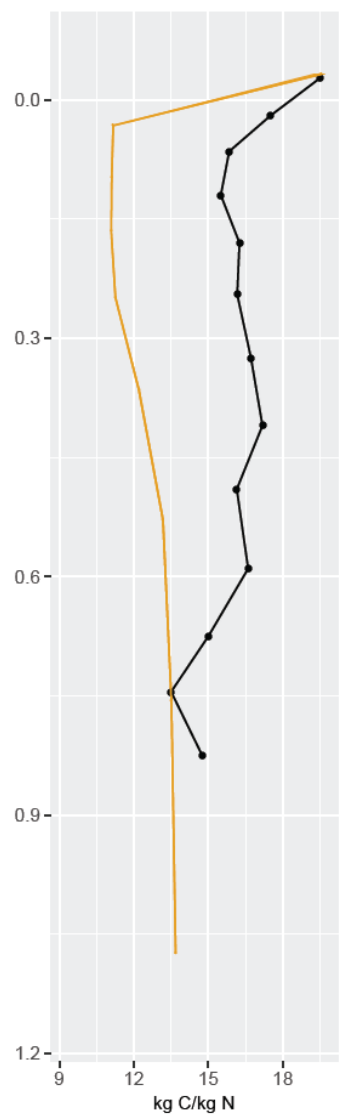

(c) SoM CP ratio

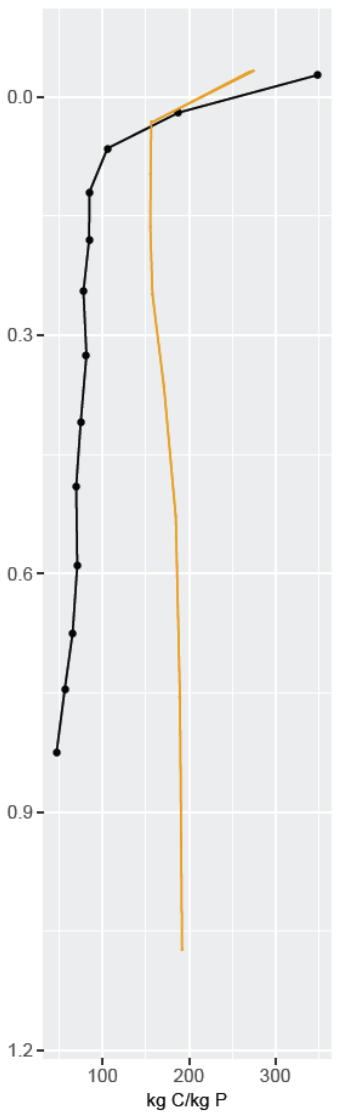

(d) Po-to-Pi ratio

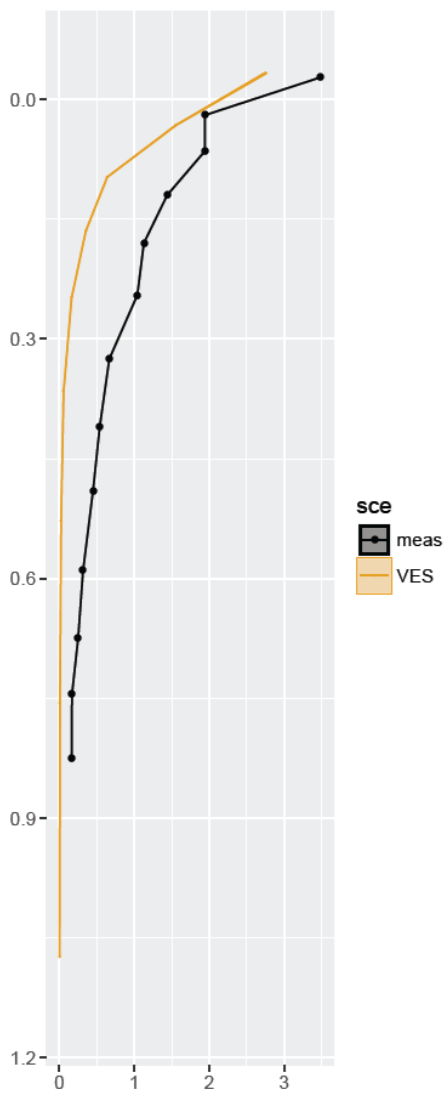

Figure S5. QUINCY simulated and observed (a) SOC content, (b) C:N ration in SOM, (c) C:P ratio in SOM, (d) organic P to inorganic P ratio in soil at the study site up to $1 \mathrm{~m}$ soil depth. Black lines and dots: observations; Organe lines and shades: simulated mean values and ranges of standard deviation using QUINCY model(Thum et al., 2019). Simulated means and standard deviations are calculated using data of the last 10 years from the model experiments. 